\title{
SOME NEST HISTORIES OF THE BLACK-BILLED MAGPIE IN SOUTHWESTERN ALBERTA
}

\author{
by Robert K. Shaw, Cardston, Alberta
}

\section{Introduction}

During the spring of 1965 a breeding population of Black-billed Magpies (Pica pica hudsonia) was studied near Cardston in the foothills of couthwestern Alberta. The purpose was to determine the density of breeding magpies within the area, egg numbers, dates of egg-laying and rearing of young, and information relative to magpie population dynamics.

The Black-billed Magpie is resident in most parts of the province except for the far north. Its range includes the foothills, the lower mountain passes, the parklands and those parts of the prairies where a bush in a shelter belt or coulee is large enough to support its nest. It was not always so numerous nor so widely distributed (Salt and Wilk, 1958).

On the treeless prairies of southern Alberta magpies maintain populations along the river-bottom forest of the major creeks and rivers and the chokecherry, serviceberry and hawthorn thickets of coulees.

\section{Description of the Study Area}

The Lees Creek valley area of this study covered about one quarter section, the west half of the NW $\frac{1}{4}-4-3-$ $25 \mathrm{w} 4$ and the east half of the NE⿺ 5-3-25w4. This land is near the south border of the town of Cardston. The Cardston Golf Course lies over part of the north side of the study area and the remainder is pastured by the local dairy herd. Lees Creek runs through the study site from the southwest to the northeast. Approximately half of the quarter section is covered with the poplar growth typical of southern Alberta river-bottom forest, and the other half is predominantly fescue prairie. In addition, a hawthorn thicket of about one acre and several small chokecherry and serviceberry thickets are within the site.

Brush and trees are dense enough for nesting sites tn escape detection. Nearby cattle feedlots and farm and ranch operations supplement magpie food supplies.

\section{Review of Literature}

Magpie nesting data for southern Alberta is scarce. For adjacent regions, Weeden (1960) reported “... two nests found in Chilkat Pass, B.C., both in spruce. A pair raised one young out of a clutch of six eggs (hatched 20 June). Another pair raised one young ....."

Brown (1957) in a study of magpies on a 6.3 square mile area in western Montana obtained over 800 nest histories. Breeding population was established at 700 birds in the springs of 1956 and 1957. In 1956, 2300 eggs developed into 1300 nestlings and these in turn into 1200 fledglings. But by spring, 1957, the total population was back down to 700 nesting birds. In 1957, 2400 eggis were laid, 1400 nestlings hatched and 1200 fledglings resulted.

Linsdale (1937) has considerable information on the nesting of the Black-billed Magpie in western North America. The average number of eggs throughout the whole range of this bird was found to be seven. Sets of nine and ten were found, and the largest recorded set was one of 13 , found in Montana. Earliest dates for eggs range from late March to early April. The distance from ground to nest ranged from a minimum of four feet to a maximum of 70 fee.t. The height of the nest seemed to be determined more by the height of available nest trees than by special preference.

\section{Methods}

The nest records in this study were obtained by examining at approximately weekly intervals all nests in use within the quarter section. Each nest was assigned a number cut into a tin can lid and nailed to the tree. 
Nest trees were identified as to genus and nest height was measured and recorded.

\section{Results}

Twenty-one nest histories were obtained. These are summarized in Table 1. From nesting data and direct observations the population of nesting magpies in the study area can be placed at 12 pairs.

Egg laying began in April and extended into June. All young magpies had left the nests by the end of June, and it was not established whether magpies raise second broods during the late summer.

Of the 21 nests followed, young magpies were raised to flight in 9 . The 9 completed nests averaged 7.0 eggs per nest. The maximum number was 9. Some egg sets were destroyed or abandoned early, and renesting by several of these pairs of magpies occurred. Twelve of the nests were destroyed or abandoned at some stage. Forty-two young magpies were raised. out of the 9 completed nests, an average of 4.7 birds per nest. The maximum number of birds to leave a single nest was 8 .

Nesit trees were mostly poplars (Populus spp.) Nest" height varied from 8 to 30 feet above ground, the average height being about 12 feet.

\section{Discussion}

In spite of all the adversities experienced by nesting magpies (predators, disease, weather, accident, and boys), this magpie population near a town of 3,000 people is flourishing. Twelve pairs of magpies had a reproductive rate of nearly $200 \%$ (24 adults raised 42 young). Losses due to death and emigration are not likely to exceed this increase.

Periodic attempts have been made in the past to destroy all the magpies

TABLE 1. Magpie nesting data southern Alberta, 1965. Figures are number of eggs; underlined figures, number of young.

\begin{tabular}{|c|c|c|c|c|c|c|c|c|c|c|}
\hline $\begin{array}{l}\text { Nest } \\
\text { No. }\end{array}$ & $\begin{array}{l}\text { Hght } \\
\text { (ft.) }\end{array}$ & $\begin{array}{l}\text { t. Kind } A \\
\text { of tree }\end{array}$ & $\begin{array}{c}\text { Apr. } \\
29\end{array}$ & $\begin{array}{c}\text { May } \\
6\end{array}$ & $\begin{array}{l}\text { May } \\
13\end{array}$ & $\begin{array}{c}\text { May } \\
28\end{array}$ & $\begin{array}{c}\text { June } \\
3\end{array}$ & $\begin{array}{c}\text { June } \\
10\end{array}$ & $\begin{array}{l}\text { June } \\
21 \mathrm{f}\end{array}$ & $\begin{array}{l}\text { No. } \\
\text { fledge }\end{array}$ \\
\hline 1. & 8 & poplar & 5 & 8 & 5 & empty & & & & \\
\hline 3. & & unknown & ... & .. & - & .. & 6 & 6 & $\underline{3}$ & $\underline{3}$ \\
\hline 4. & & unknown & & & & $\cdot$ & 2 & 1 & empty & \\
\hline 5. & 20 & poplar & & 3 & 7 & empty & & & & \\
\hline 6. & 8 & poplar & 5 & 9 & 8 & 7 & $\underline{6}$ & $\underline{6}$ & empty & $\underline{6}$ \\
\hline 7. & 18 & poplar & 7 & 8 & 8 & $\underline{8}$ & $\underline{8}$ & empty & & $\underline{\overline{8}}$ \\
\hline 8. & 8 & poplar & 2 & 8 & 6 & empty & & & & \\
\hline 9. & 12 & poplar & .. & 1 & 4 & 4 & $1-\underline{2}$ & $\underline{2}$ & empty & $\underline{2}$ \\
\hline 10. & 12 & poplar & 9 & 9 & .. & 8 & 8 & empty & & \\
\hline 11. & 10 & poplar & 2 & 4 & 4 & 4 & 4 & empty & & \\
\hline 12. & 12 & poplar & 2 & 7 & 7 & empty & & & & \\
\hline 13. & 8 & poplar & .. & & & .. & 6 & $\underline{4}$ & empty & $\underline{4}$ \\
\hline 14. & 8 & hawthorn & n 8 & 9 & 9 & 4 & $\underline{4}$ & empty & & $\underline{4}$ \\
\hline 16. & 15 & poplar & & 4 & 7 & $1-7$ & $\underline{5}$ & $\underline{5}$ & empty & $\underline{5}$ \\
\hline 18. & 10 & poplar & 2 & 6 & 7 & empty & & & & \\
\hline 19. & 12 & birch & 6 & 7 & empty & & & & & \\
\hline 20. & 30 & poplar & .. & 6 & 8 & $\underline{4}$ & $\underline{4}$ & empty & & $\underline{4}$ \\
\hline 25. & 10 & poplar & 1 & 4 & empty & & & & & \\
\hline 27. & 10 & poplar & & 1 & empty & & & & & \\
\hline 28. & 15 & poplar & 7 & 8 & 9 & 8 & empty & & & \\
\hline 29. & 20 & poplar & .. & 5 & 6 & $\underline{7}$ & $\underline{6}$ & $\underline{6}$ & empty & 6 \\
\hline \multicolumn{3}{|c|}{ Total eggs. } &. .56 & 105 & 94 & 25 & 27 & 7 & & \\
\hline \multicolumn{3}{|c|}{ Total young } & & & & 37 & $\underline{35}$ & $\underline{23}$ & $\underline{8}$ & 42 \\
\hline
\end{tabular}


in the Lees Creek valley. These efforts, carried out under the bounty system, have been unsuccessful. The higher reproductive potential of a reduced population and the fact that bounties were paid on the easily collected young magpies, many of which would die anyway, are facts now fairly well understood by most sportsmen's groups.

Magpie population and nesting $\mathrm{dy}$ namics in this study compare favorably with Brown's (1957) results. Here on Lees Creek, density of breeding hirds was 24 per quarter section. On Brown's 6.3 square mile area in Montana's Bitterroat Valley the density was 28 birds per quarter section. Reproductive rate for Lees Creek was
42 young birds per quarter section and in Montana 50 per quarter section. Average number of eggs per completed nest reported by Linsdale (1937) was 7 ; by Brown, 6.7; and in the Lees Creek, 7.0 eggs per nest. Average number of young magpies to leave the nest in Montana was 3.4; on Lees Creek it was 4.7.

\section{LITERATURE CITED}

Brown, R. L. 1957. Magpie ups and downs. Bull. No. 3, Montana Fish and Game Dept., Helena, Montana.

Linsdale, J. M. 1937. The natural history of magpies. Pub. No. 25, Cooper Ornithological Club, Berkeley, Calif.

Salt, W. R. and A. L. Wilk. 1958. The birds of Alberta. Queen's Printer, Edmonton.

Weeden, R. B. 1960. The Birds of Chilkat Pass, British Columbia. Can. Field-Nat., 74 :119129.

\section{BLACK-THROATED BLUE WARBLER REACHES BELCHER ISLANDS, N.W.T.}

\section{by Stanley Zazalenchuk, Belcher Islands}

I was much excited when on October 20, 1966 a male Black-throated Blue Warbler (Dendroica caerulescens) was sighted and later unexpectedly collected in an odd manner. Upon returning to class after the the morning recess several children reported seeing a small blue and white bird which was apparently seeking shelter under the eaves of a house. I quizzed the youngsters, but even then was unable to attempt a satisfactory guess as to what it might be. Regretfully, I went to lunch, wishing I had seen the bird myself. While I was still thinking about this and preparing my lunch two boys came in. Johnny called out, "Isaac got the bird!" Sure enough, there was Isaac holding a small, ruffled bird. I recognized it immediately as a male Black-throated Blue Warbler. Peterson's Field Guide to the birds confirmed my identification.

The range of this warbler as given by Peterson is southern Quebec and southern Ontario, where it breeds in the undergrowth of deciduous and mixed woodlands. I then checked Snyder's Arctic birds of Canada, but found no mention of a record of this June, 1967 species.

The Belcher Islands are a group of islands in Hudson Bay, approximately 70 air miles west of the Quebec mainland. Our settlement is located approximately at a latitude of $55^{\circ}$ $54^{\prime}$. The islands are devoid of any trees except stunted dwarfed willows a foot or so in height. I assume that the warbler got sidetracked from his regular route, as the islands are obviously far beyond its normal range.

It is possible that the relatively cool temperature on October 20, somewhere in the low forties, hindered the bird's activity and caused it to seek shelter, for during the two hours after the first sighting, it flew only several hundred yards, then settled into the grass where young Isaac spotted it on his way home from lunch. Owing to his ability to pitch a small stone with unusual accuracy we have now established beyond any doubt the occurrence of the Black-throated Blue Warbler in this northerly region. I plan to prepare the bird as a study specimen and donate it to the collections of the National Museum at Ottawa. 